\title{
ETHNO-CULTURAL PARALLELS \\ IN THE SEMIOTICS OF THE ARCHITECTURAL DECOR OF MODERN STYLE PERIOD IN SIMFEROPOL
}

\author{
Elena Kotlyar \\ Crimean Engineering and Pedagogical University, Simferopol, Russia \\ allenkott@mail.ru
}

The essence of the study consists in symbolic and semantic analysis of the main circle of architectural decor elements, specific to the decorative and applied art of Crimean nations. The main objectives of the study include general characteristic of Crimea, as a multi-ethnic region, saturated for many centuries with a variety of cultural later developments, which were reflected in arts and crafts as well as architecture. Due to such a variety in the architectural decor Crimea, lots of symbolic pictorial elements are traced, for which reason the author faces two more tasks: identification through the method of historicism and the comparative semantics method of each symbol and belonging thereof to a particular ethnic culture. Symbolism and allegorical character of decorative images are also associated with the long-term formation of Islamic pictorial culture in Crimea, based on plant and geometric elements, and wide influence thereof on the art of surrounding nations. Temporal area of the study covers the period of the late $19^{\text {th }}$ - early $20^{\text {th }}$ centuries, when Art Nouveau comes to the Crimean architecture, the overall elegant eclecticism of which contributes to the introduction of various elements of the national decor. Decor elements of buildings could indicate the ethnicity of their owner, and also contributed to the formation of the so-called "Crimean style" in the architecture of the region, which is characterized by an abundance of small "lacy" molded elements, elegant ornamentation, light colors of the facades, which, in combination with a predominantly blue sky, creates characteristic southern charm of the city.

Keywords: Crimea, Simferopol, Art Nouveau, architecture, ethnic ornament, eclecticism. 


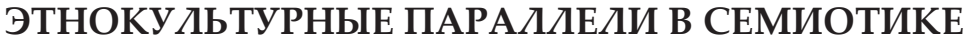 АРХИТЕКТУРНОГО ДЕКОРА СИМФЕРОПОЛЯ ПЕРИОДА МОДЕРНА
}

\author{
Е.Р. Котляр \\ Крымский инженерно-педагогический университет, Симферополь, Россия \\ allenkott@mail.ru
}

Целью данной статьи является символико-семантический анализ основного круга элементов архитектурного декора, характерных для декоративно-прикладного искусства народов Крыма. К основным задачам исследования можно отнести общую характеристику Крыма как полиэтнического региона, насыщенного на протяжении многих веков разнообразными культурными наслоениями, которые находили отражение в декоративно-прикладном искусстве и архитектуре. Вследствие такого многообразия в декоре архитектуры Крыма прослеживается множество символических изобразительных элементов, в связи с чем перед автором встают ещё две задачи: идентификация с помощью метода историзма и компаративистского метода семантики каждого из симводов и определение его принадлежности к той или иной этнической культуре. Символизм и иносказательность декоративных образов связан также с многодетним формированием исламской изобразительной культуры в Крыму, базирующейся на растительных и геометрических элементах, и её широким влиянием на искусство окружающих народов. Временным ареалом исследования является период конца XIX - начала XX вв., когда в крымскую архитектуру приходит стиль модерн, общая нарядная эклектичность которого способствует внедрению разнообразных элементов национального декора. Элементы декора зданий могди указывать на этническую принадлежность их владельца, а также способствовади формированию так называемого «крымского стиля» в архитектуре региона, который характеризуется обилием мелких «кружевных» лепных элементов, нарядной орнаментальностью, светлым цветом фасадов, что в сочетании с преимущественно синим небом создаёт характерный южный колорит города.

Кдючевые слова: Крым, Симферополь, модерн, архитектура, этнический орнамент, эклектика.

DOI 10.23951/2312-7899-2019-3-98-112

For many centuries Crimean Peninsula was the historical center of the intersection and interaction of many national cultures, the meeting point of the East and West, accumulating the traditions of various 
peoples and ethnic groups within its borders. In the conditions of compact residence of representatives of different nations on the territory of Crimea, the flow and merging of some cultural edges with others as well as formation of a single cultural landscape became inevitable [Berestovskaya 2016, 6-7], which was clearly manifested in languages, traditions, architecture, arts and crafts etc. This, in turn, makes relevant two trends of research: study of the "Crimean style" as such, or the synthesis of various cultures in individual areas of applied artistic ethnography, and the search for individual cultural codes - foundations of historical ethnic memory, the fragmentation of the identity of each nationality participating in cultural integration. In respect to arts and crafts these cultural codes are expressed both in the semiotics of individual pictorial and ornamental elements, and in the peculiarities of stylistics thereof [Gachev 2007, 30-31].

In the cultural codes that form the basis of the historical memory of nations long ago living in Crimea, in particular Greeks, Armenians, Crimean Tatars, Karaites, Krymchaks, there are obvious parallels determined by the centuries-old compact living on a single territory of the peninsula [Berestovskaya 2016, 12; Bibler 1975, 246]. Similar features of a number of ethnic groups are expressed in language, customs, folklore, cuisine, clothing, and some features of liturgical practice. Thus, Karaite and Krymchak languages are ethnolects of Crimean Tatar language and belong to the Kypchak group of Turkic languages [Musaev 1964, 6], [Kizilov 2011, 152, 174]. Some parallels of exegesis of a single sacred source - the Pentateuch, as well as the presence of religions of the Crimean ethnic groups of even more ancient, pagan beliefs in the cultural code constitute an important nuance. Thus, in the Karaite and Krymchak practices, the worship of the god Tengra at the sacred oak takes a particularly important place, which is common to the pre-Islamic beliefs of the Turkic peoples [Zakoka 2009, 113; Andrievskaya 2012, 157-161; Beliy 1994, 32-33]. These nuances make an impact on the similarity of interpretation and stylistics of a certain symbol in the decorative and applied art of Crimea, allowing us to talk about a single cultural continuum [Likhachev 2006, 120; Lotman 1992, 195; Astafieva 2016, 24].

With the expansion of Art Nouveau in the Crimean architecture in the late $19^{\text {th }}$ - early $20^{\text {th }}$ century [Sarabyanov 1989,4 ], which was a kind of architectural eclecticism, the world art styles (neoclassicism, NeoGothic, Neo-Baroque) and the outstanding characteristics of the national art of nations inhabiting the Crimea-Crimean Tatars, Armenians, Krymchaks, Karaites, Greeks and others - appeared in the designs and 
decor of the mansions and public buildings [Kovalenko 1999, 51]. The purpose of this study is to identify and determine the semantics of certain outstanding elements of architectural decor as exemplified by architectural monuments of the city of Simferopol of the Modern period.

The Art Nouveau style has spread everywhere in architecture, arts and crafts and fine arts both in Western and Eastern Europe, and in Russia in the last third of the $19^{\text {th }}$ - the first third of the $20^{\text {th }}$ century. The main differential characteristics of the "new style" included the appeal to natural curvilinear forms, elegant decorating, which spread not only in the decorative and applied art and interior, but also in the overall design and decoration of architecture [Okhotnikova 2014, 10-11]. Modern era liked images of stylized natural forms, intricate vignettes made of interlaced plant, flower stems, creating a common elegant background. Ornamental type of composition prevailed both in the monumental painting, and in the design of decorative and applied arts. The plastic of decor was attracted towards the accentuated decorativeness, representing a continuous or linear rapport made of vegetable segments, with inscribed larger composite elements, for example, figures of people, animals, birds, vases, etc., inscribed into oval, round or arched cartouches.

Curvilinear natural forms prevailed not only in the bizarre design of fence grids, plastic forms of stained glass, stucco moldings, wood carvings, tapestries, but also dictated the choice of unusual compositional techniques in the layout of building facades that abound with omega-shaped window and door openings, often located asymmetrically in regard to the facade; previously rectilinear lines of cornices, arches, and especially the decor of the facades also often acquired a free, curvilinear silhouette [Sarabianov 1989, 10-12]. French critic Charles Blanc wrote about the architecture of Art Nouveau: "Architecture in its highest sense is not a building that is decorated, but a decor that is built" [Rempel, Vyaznikovtseva 1935, 91]. An architect, according to Blanc's idea, is the "builder of decorations". According to A. I. Kovalenko, "relief ornamentation (of Art Nouveau) merges with the form, becomes inseparable from it. It is impossible to draw a line between the ornament symbolizing the structure, and the real structure, which was ornamentally interpreted" [Kovalenko 1999, 52].

Despite some common features that allow attributing a certain architectural construction to the period of Art Nouveau, all buildings designed in this style are distinguished by a pronounced individuality, eclecticism of elements borrowed from different styles of world architecture, and, in a number of examples, by regional and ethnonational color. 
This, in particular, is due to the fact that mansions and sometimes public buildings were built with due regard to the user stories, and accordingly, could contain elements of the national artistic culture. The most striking examples include Vorontsov Palace in Alupka, built in the eastern Moorish style, dacha Victoria in the city of Feodosiya, full of Karaite symbols, and others. Eastern style is often traced in the layout and decoration of the architecture of the Art Nouveau period in Crimea, which style is a fusion of elements of Turkish and Arab art of building, Armenian architecture, Crimean Tatar constructions of the Golden Horde time, Karaite elements [Kalinin, Zemlyanichenko 2004, 8-13]. Crimean architecture of Art Nouveau period as in other regions of Russia and Europe, elements of antique classicism, Baroque and Gothic are manifested together with ethnic elements, to a greater or lesser degree depending on the nature of the building and the preferences of the client [Danilevsky 2011, 230]. But, according to A. I. Kovalenko [Kovalenko 1999, 53], the regional nature of Crimean buildings is almost always distinguishable due to the fact that: "In this case the East and ancient Greece always served as a dominant for Crimea. That's why the 'symbiosis of traditions' in the architectural monuments of Crimea has its own unique plastic appearance, which makes it possible to accurately recognize its geographical origin".

"Crimean Style" (as defined by E. A. Aibabina) in the decorative and applied art and architecture of the peninsula was formed over the centuries on the basis of the Scythian-Sarmatian art, experiencing the influence of certain traits introduced during the migration of nations, and later Seljuk art, "style principles of which were transferred to the Crimean soil by Armenian masters" [Lotman 2000, 322-323; Aibabina 2001, 8; Berestovskaya, Bryzhak 2015, 61-62]. "A number of researchers believe that in the Crimean environment the decoration of constructions does not depend on their confessional identity and the typical decor is found on the monuments of the Christian and Muslim spheres" [Orbeli 1963, 154].

The images formed over the centuries in Crimean (Crimean Tatar, Karaite, Krymchak) folk art included subjects that had their own semantic significance, expressed through symbolic, allegorical or metaphorical forms. Due to religious prohibitions on human images, groups of individual plots and motifs were created that replaced the human image or expressed human benefactors [Dombrovsky, Sidorenko 1978, 54-55]. They included stylized images of symbolic animals, skeuomorphic motifs - images of everyday objects and objects of the cult, however, basically the figurative-stylistic number of images is represented by 
significant plant and geometric patterns, due to the proximity and mutual influence of the Crimean Tatar counterparts [AkchurinaMuftieva 2008, 214-215]. An important role was played by the ornament also in Greek, and especially in Armenian decorative and applied art and architecture, where images of people, animals and birds are found, but their plastic is maximally stylized and subordinated to the general rhythm of the ornament, as a result of which the figures are perceived only as part of it (which subsequently complied with the plastic message of Art Nouveau).

A number of buildings along one of the central streets of Simferopol Pushkin street (former Priyutninskaya) may be considered as examples of applying the plastic of Art Nouveau. The monuments of the Art Nouveau period, which gave the city a unique, recognizable color, include the Noble Theater (now the main stage of the Gorky Theater), the former City Duma and the government (now the building of the Philharmonic Hall, 1-3 Pushkin Street), the former city club building, and later the Metropol Hotel (now the Officers' House, Pushkin Street, 8). A lot of mansions and tenement buildings on this street belonged to businessmen, brothers Schneider: Pyotr, Nikolay, Franz and their children, as well as other entrepreneurs and public officers - I. I. Vodotsian, O. A. Semerdzhiev (fig. 1) and others.

The street was previously named "Priutinskaya" or "Priutninskaya" due to the building of a shelter for orphan girls (Pushkin St., 18), where the Crimean ethnographic museum is currently located. The building is not distinguished by an abundance of decor, although the semicircular windows of the first floor and slightly rounded windows of the second floor, decorated in the upper part with an arcade encircling the facade, give out a characteristic color of official architecture of the late $19^{\text {th }}$ century. On the same street there were two more shelters - for orphan boys, and a night shelter. In 1899, the street was renamed Pushkinskaya, and then, in Soviet times, Pushkin.

Pushkin street, 16 is the address of one of the most picturesque buildings with elegant decor, built in 1890 - Erganov's mansion, later owned by one of the leaders of the factory inspection, merchant I. I. Vodotsian (fig. 2). In 1909, this building was a women's club, headed by a representative of honorary citizens of the city, Sofia Schneider (born Nalbandova). The club held classes in foreign languages, there were clubs for preschool education, the legal status of women, reports and readings were arranged. At the moment regional dentistry is in this building. 


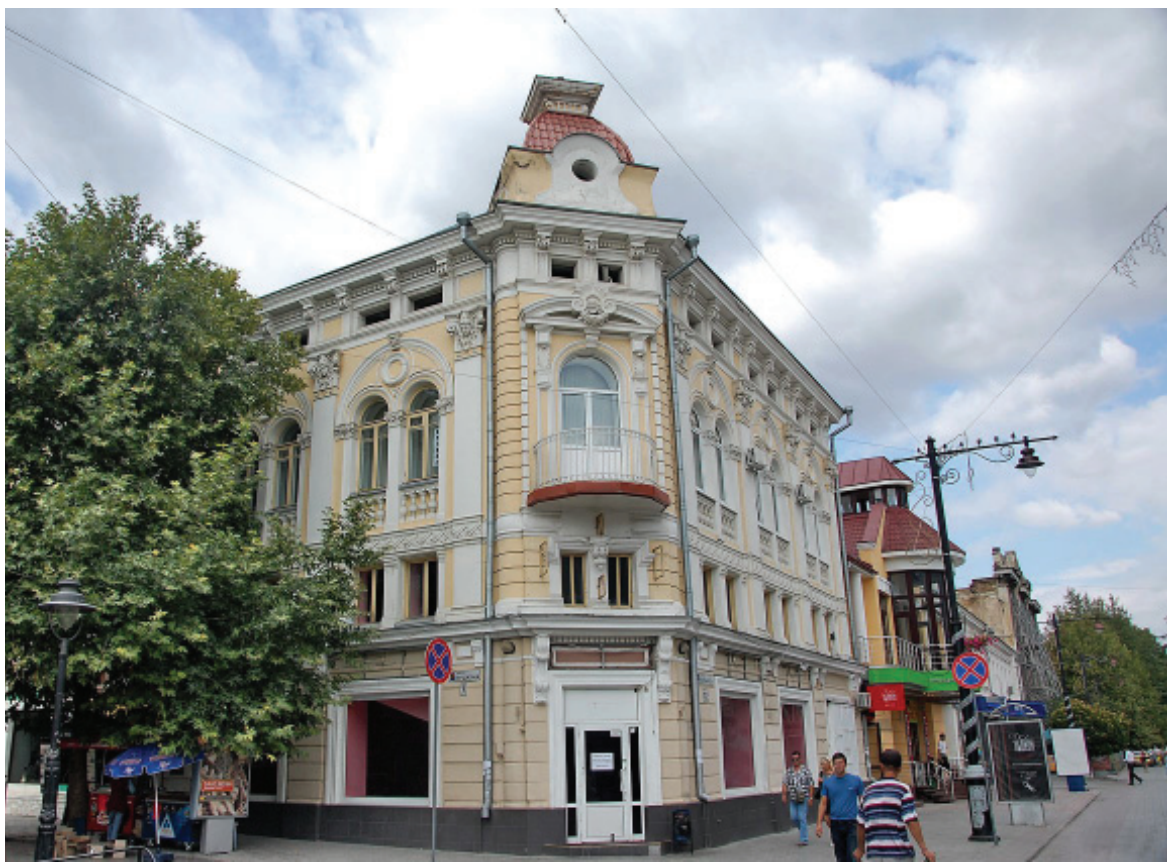

Fig. 1. The former manufactory of the merchant Semerdzhiev (built in the late XIX century)

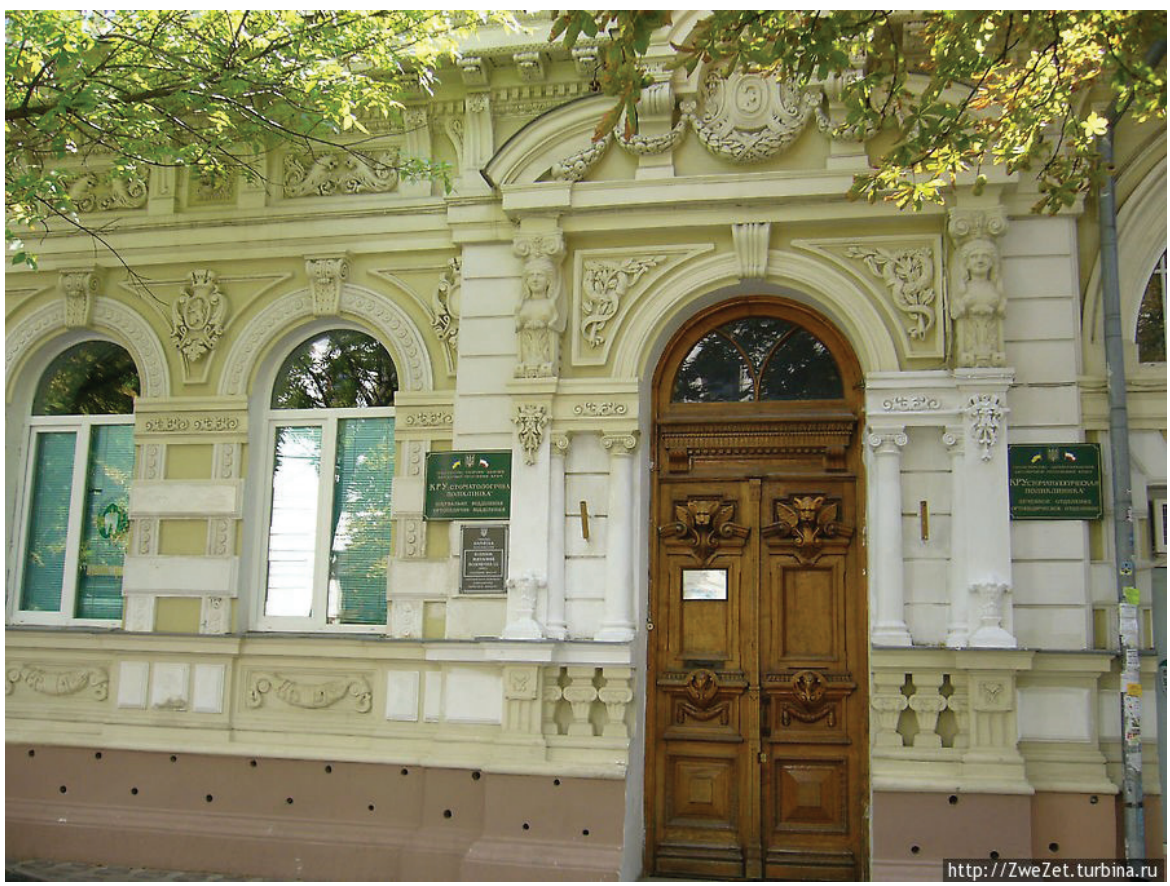

Fig. 2. Regional dentistry, the former mansion of I. I. Vodotsian (built in 1890) 
The decor of the building can serve as one of the most distinctive examples of the Crimean architecture of Art Nouveau, in which traits borrowed from different styles and eras are traced. The building is a single-storied elongated construction with several entrances, and thus resembles a tenement building designed for renting apartments (perhaps for this purpose it was built by the first owner) [Kovalenko 1999, 51].

The overall construction of the building has characteristics of classicism: thus, its facade is divided across into five parts (tiers). The upper part of the building, above the cornice, is decorated with a balustrade with pot-bellied columns. The frieze tier is divided by vertical extrusions, like triglyphs, into several sectors-metopes, with sculptural reliefs. A number of windows and doors on the facade have a semicircular perfection and are framed by ionic half-columns and sculptured molded reliefs. The tier between the windows and the foundation line also has vertical decorative divisions with reliefs between them. At the same time, the proportions of structural elements: large cornice overhang, large (in comparison with the shafts), column capitals, deep window cuts, as well as an abundance of enlarged relief molded decor elements, create a general impression of the building's belonging to the Baroque style. At the same time, plastic sculptures and architectural elements (for example, capitals, carved wooden high reliefs on door panels, cornice decorations, etc.), is a kind of fusion of European Baroque and Crimean decorative art, in particular, Scythian-Sarmatian one, manifested later in the decorative and applied art of a number of Crimean nations.

Thus, the Baroque plasticity includes a crowned monogram in the form of symbol " $\mathrm{E}$ " in a cartouche-scroll above the entrance, which is a symbol of power, and a wreath made of intertwined laurel leaves, quince and grapes interwoven with a ribbon. At the same time, the fruits are specific for the Crimean land: viticulture is one of the most ancient kinds of agricultural crafts in Crimea, so this motif is similar in the ornamentation of many nations. It is found in the decor of Christian churches (especially Armenian ones), and in the Karaite and Krymchak figurative-plastic series, and in Crimean Tatar plastics [AkchurinaMuftieva 2008, 202-203].

The wreath and monogram on the facade are surrounded by small "curly" elements, quirks, which gives them an oriental, "arabesque" tone. Numerous images of fruit bundles hanging on cords, found in the decor of the Crimean Art Nouveau buildings, are borrowed from the European Baroque style. The same can be said about other plant elements 
of the relief that frame the entrance: cartouches with lions in the vegetable frame on the sides of the door, a wreath with a laurel branch in the middle, and others. The bas-relief on the frieze, which realistically depicts the face of a lion - an element the etymology of which goes back to court hunting halls with trophies - is typically Baroque [Kotlyar 2015, 325-327].

The frieze ornament dividing the space along the facade above the door has a general pronounced Turkic nature, repeating the pattern of "mutton horn", specific for the Crimean Tatar and Karaite decorative and applied art [Chepurina 2005, 493]. Busts-caryatids on both sides of the door are at first glance close to the ancient sculpture, however, the curls of the capitals and the plant element under the bust, when examined in detail, turn out to be the elements of the Crimean floral ornament "flower pot", common to the Crimean Tatar, Karaite and Armenian art. It is worth noting that the ancient art on the territory of the Crimea (Bosporus, Chersonese) was also largely influenced by the Scythian-Sarmatian art, which can be clearly seen in the capitals of the survived columns, wall paintings and vases.

Very interesting are the elements on the frieze of the building. Structurally this is a vegetative ornament, common to the art of the Crimean Tatars, Karaites, Armenians - in the form of the S-shaped bent branch "Egri-dal", which is a symbol of the flow of life, the cycle of time. This motif is traditionally favorite in the Crimean decor of Art Nouveau, found as a branch with flowers, fruits, leaves, or simply in the form of curls-tendrils. However, in this example, at the ends of branches facing each other, there are stylized heads of lions - a symbol of power, of the might of Earth, and the opposite ends turn into tails. The image of these animals can be borrowed from both Scythian-Sarmatian art and from later Gothic plastics, for which the image of chimeras was specific (Tsalik 2012), [Sarach 1997, 210]. A griffin, in particular, was used in the heraldry of the ancient Chersonese and Panticapaeum, although the etymology of this image dates back to the Asia Minor art. The same can be said about the plastics of wooden high reliefs on the doors, depicting winged lions and eagles. Chimera dress up a lot of Crimean buildings of the Art Nouveau period: it is worth mentioning one of the most recognizable buildings in the center of Simferopol - the famous "House with Chimeras" - the mansion of merchant Chirakhov at the corner of Odesskaya and Kirov streets, decorated with images resembling sea horses with wings and bird heads; scaly dragon lizards with a bird head and a toothy beak, decorate the facade of the mansion on Kirov street, 44 , etc. 
The original molding, the motives of which are obviously borrowed from the traditional art of Crimea, dresses up the mansion of sworn attorney E. V. Wulf, which later housed the branch of St. Petersburg Commercial Bank, and now is the Museum of the History of Simferopol [Kilesso 1983, 64]. The mansion is built in a classical style, the laconic layout of a single-storied building is decorated, just as in the building of dentistry, with the upper gallery above the cornice, and two small arched gables above the entrance and one of the windows. The decor of the molding is more rigorous than in the previous example and is limited to lowly protruding relief elements above the windows and in the frieze part. The very nature of the image, reminiscent of the traditional Crimean Tatar, Karaite and Armenian embroidery is interesting: above the windows, in the middle, there are flowerpots with small plant elements, the same small plant and floral images are found on the decorative brackets on the sides. Elements of a frieze plant ornament in the form of a number of palmettes above the entrance (originally signifying fame and honor) are borrowed from the Asia Minor and then Greek art. Quatre foiled rosettes with small palmettes in each foil under the windows, are interesting. The image of rosettes with different number of foils (four, five, six, seven, or more), in the meaning of the solar symbol, the oldest for many nations, is frequently found in the Crimean art. This motif has ancient roots that go back to the culture of the TaurusScythians [Asanova 2002, 35].

The building of the photo studio, with the survived inscription with the pre-revolutionary orthography "Photographia" - the house of merchant Semerdzhiev (Pushkin Street 7 / Ekaterininskaya street, 12), is also distinguished by an elegant decor. The building was originally built as a complex of manufactory shops and ateliers. The style of the building can be characterized as classicism, which includes elements of the Renaissance Baroque. This idea is prompted by double windows with semi-circling tops and "false" railings with relief half-balusters under them (like an Italian balcony), pilasters decorated with angels' heads, a cut corner with a semicircular balcony, topped with a small attic, brackets under the cornice in the form of helix-crowned pilaster-strips, decorated in antique style [Okhotnikova 2014, 18]. The original solution is to use two scales of pilasters: Large on the sides of the double windows, and small on the sides of each window. The asymmetrical facade is the original dominant of central streets, giving them an elegant, festive look. Facade from Pushkin street over the entrance to the photo studio (which has the same purpose for more than 100 years) is also decorated with a semicircular pediment projecting upwards with a molded 
overhang in the form of a cartouche, and caryatids in antique style supporting a triangular cornice above the entrance. The impression of elegance is enhanced by decorative wreaths made of fruits and laurel branches framing the brackets above the windows. Numerous palmettes give the eastern tone to the building [Baeshko 2007, 186].

Renaissance elements are inherent in other buildings on Pushkin street, for example, the house of merchant I. M. Levitan on Pushkin street, 19/11 (today the building houses P. I. Chaikovsky Children's Music School). In particular, a semicircular pediment with an attic above it, an Italian balcony, ionic columns framed with wreaths and brushes, a round lunette above the balcony, double windows with a semicircular top are typical for a light, easy Italian style, a mixture of Classicism, Renaissance and Baroque [Asanova 2002, 36]. Renaissance easiness and at the same time a pronounced character of Art Nouveau are inherent also in the plant decoration of the building along Pushkin street, 11 (the house where the famous creator of the army of defense of Israel, the St. George cavalier, the hero of the Russian-Japanese war Joseph Trumpeldor stayed). Reliefs on the facades depict the vining branches of a composite plant, reminiscent of a snowball tree. The bizarre bends of the branches in one case resemble the S-shaped motif of Egri-dal [Fakhrutdinova 2011, 23], in another version, above the entrance, they show the typically modern fanciful lines and minimal stylization.

The next building on Pushkin street, 19, which now houses the Center for Variety Art, is quite original: having geometric trapezoidal lines of the facade, the building is decorated with antique Greek elements: reliefs in the form of a classic laurel wreath on the pediment and three shields with a meander in the middle, above the entrance. The use of the traditional Greek meander ornament is frequent and typical for the decor of the Crimean architecture, in particular, it decorates the facade of the house on Pushkin street, 26, and other buildings [Prokhorov, Khrapunov 2013, 58-59].

A slightly different impression is made by another well-known mansion belonging to Franz and Sophia Schneider, in which the House of Marriages is now located. The asymmetric structure of volumes with the displacement of the entrance to the right edge of the facade, its framing with somewhat heavier Baroque Corinthian columns and a covered gallery with a marble balustrade overhanging the windows of the facade, the even overlapping of finials makes the building the product of a unique synthesis of styles and eras. On the other hand, other Simferopol buildings of the Art Nouveau period, for example, the church of Mary Magdalene, Constantine and Helen, as well as the 
famous Noble Theater, have a similar layout with asymmetric geometric volumes and a displaced entrance.

The building of the former Noble Theater (now the Gorky Theater) (fig. 3) is in general quite different from other buildings on Pushkin Street and the city as a whole. It was designed in 1911 by academician of architecture A. N. Bebeto. The building is constructed in the style of the ceremonial classicism, specific for large cities and squares, such as, for example, Kharkov, where Beketov formed the main image of the city. The theater's face vividly demonstrates the creative mannerism of the famous architect, its facade resembles the building of the Noble Assembly in Kharkov and other constructions of Beketov. Despite the fact that, in comparison with Kharkov, there is a lack of space in front of the building, due to which it is impossible to view it in whole, it is certainly a bright dominant of Pushkin street, standing out by its scale and proportions from the general environment of elegant "curly" decor of surrounding buildings. Both large scales of the order elements (columns) and round sculptural groups are uncommon for Crimea: as a rule, small relief corbels were used in the Crimean buildings of the Art Nouveau period. The exception is provided by sculptured lions in front of the facades and stairs of the palace complexes.

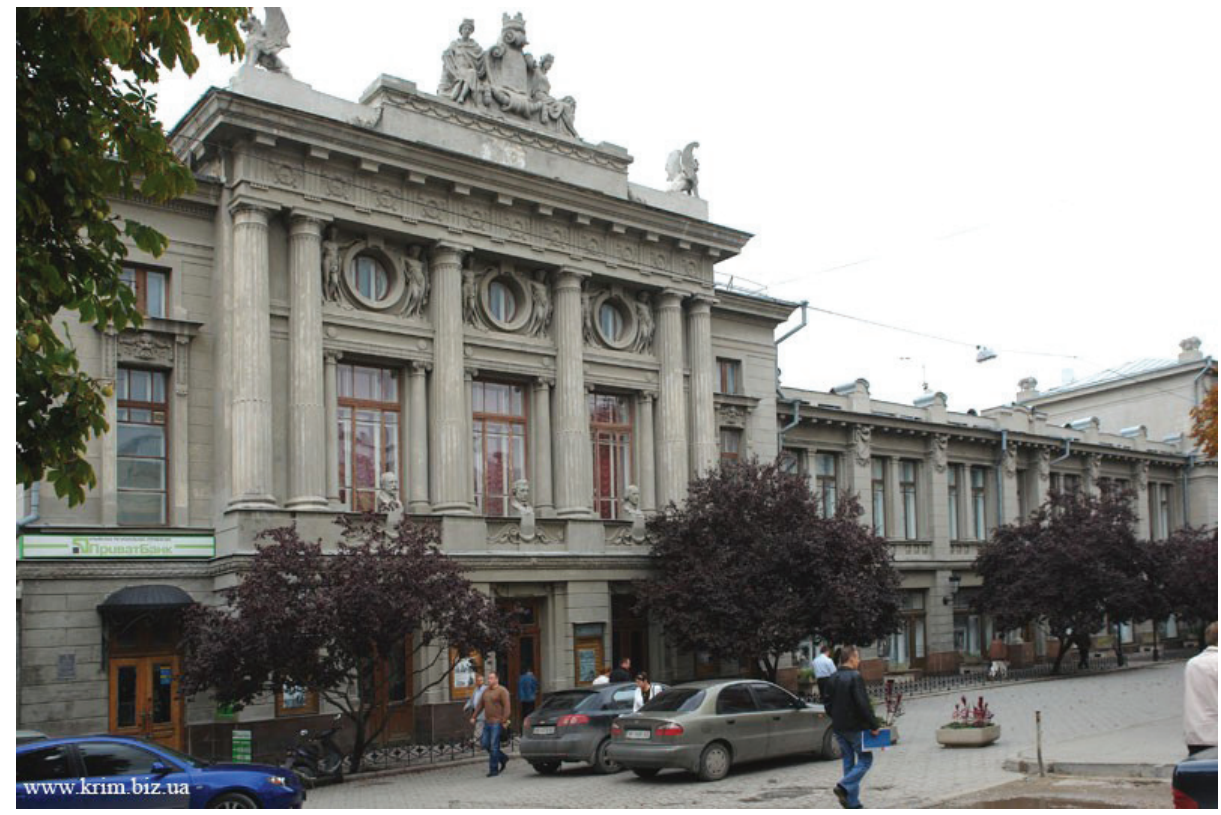

Fig. 3. Main stage of M. Gorky Crimean Academic Russian Drama Theater (former Noble Theater, built in 1911, architect A. N. Beketov) 
The rectangular facade of the building is on both sides crowned by towers with almost flat ceilings, decorated with galleries with massive columns. In addition to three large rectangular windows the front facade has three more round windows framed by supporting sculptures. The gallery of the second floor of the front facade is crowned with busts of A. S. Pushkin (at its center), P. I. Tchaikovsky and M. A. Glinka.

The attic over the front door is decorated with a sculptural group of Apollo Belvedere and Melpomene, holding a crowned scroll with a libretto, and winged lions on the sides of the facade. Other decorative elements are caryatids in the form of female figures in antique tunics, one of which holds a mask in her hand; there are sculpted images of the masks of ancient theater heroes above the windows of the facade to the left and to the right of the central entrance; there are laurel wreaths in the metopes above the entrance

Analyzing the structure and decor elements of the Crimean mansions and public buildings, even on the example of one central street of Simferopol - Pushkin street, we can conclude that at a common elegant decorativeness specific for the stylistics of Art Nouveau, which includes elements of European stylistics - Baroque, Gothic, Renaissance, lots of facilities have pronounced features of regional Crimean plastics. These are elements of Scythian-Sarmatian art, and features of ancient Polis of the Black Sea region, and traditional decorative and applied art of numerous Crimean nations. The ethnocultural synthesis of the centuriesold heritage of Crimean art was embodied in the distinctive and recognizable regional appearance of buildings of Crimean cities: Simferopol, Yevpatoria, Yalta, Feodosia.

It is not by chance that the griffin - a mythical animal consisting of three different species - is in the center of the Crimean coat of arms. "Prosperity in Unity", as also evidenced by the beauty embodied in the stone chronicle of the Crimean Art Nouveau style.

\section{REFERENCES}

Aibabina 2001 - Aibabina E. A. Decorative stone carving of Kaffa XIVXVIII centuries Simferopol, 2001. In Russian.

Akchurina-Muftieva 2008 - Akchurina-Muftieva N. M. Decorative and applied art of the Crimean Tatars. Simferopol, 2008. In Russian.

Andrievskaya 2012 - Andrievskaya I. Y. On the issue of the Krymchaks community of Evpatoria. Ethnography of Crimea of the XIX-XX century 
and modern ethno-cultural processes: Materials and research. 2012. 2. P. 157-161. In Russian.

Asanova 2002 - Asanova E. Universal language of patterns (about the national embroidery of the Crimean Tatars). Qasevet. 2002. 1 (29). P. 33-37. In Russian.

Astafieva 2016 - Astafieva O. N. Dialogue as an instrument for overcoming the "risks of culture": modeling of practices of intercultural interaction. The World of Culture and Culturology. Almanac of the Scientific and Educational Cultural Society of Russia. 2016. 5. P. 20-31. In Russian.

Baeshko 2007 - Baeshko L. S. Encyclopedia of symbols. Moscow, 2007. In Russian.

Beliy 1994 - Beliy O. B. From the history of the Karaite community of Crimea in the late $18^{\text {th }}-$ early $20^{\text {th }}$ century. The Crimean Museum. 1994. 1. P. 32-33. In Russian.

Berestovskaya 2016 - Cultural landscapes of Crimea: multi-authored monograph. Ed. by D. S. Berestovskaya. Simferopol, 2016.

Berestovskaya, Bryzhak 2015 - Berestovskaya D. S., Bryzhak O. V. Dialogics of a holiday (as exemplified by the culture of Crimean nations). Simferopol, 2015.

Bibler 1975 - Bibler V. S. Thinking as creativity: Introduction to the logic of a mental dialogue. Moscow, 1975. In Russian.

Chepurina 2005 - Chepurina P. Y. Ornamental sewing of Crimea. Crimean Tatars: Readings on the ethnic history and traditions. Ed. by M. A. Aradzhioni, A. G. Gertsen. Simferopol, 2005. P. 493-501. In Russian.

Danilevsky 2011 - Danilevsky V. Y. Russia and Europe. A glance at the cultural and political relations of the Slavic world towards the German-Romance one. Moscow, 2011. In Russian.

Dombrovsky, Sidorenko 1978 - Dombrovsky O. I., Sidorenko V. A. Solkhat and Surb-Khach. Simferopol, 1978. In Russian.

Fakhrutdinova 2011 - Fakhrutdinova F. D. Folk costume as a reflection of interaction between Russian and Tatar cultures in the south of the Tyumen region in the XIX - early XX century: dissertation of the candidate of cultural studies. Chelyabinsk, 2011. In Russian.

Gachev 2007 - Gachev G. D. National images of the world. CosmoPsycho-Logos. Moscow, 2007. In Russian.

Kalinin, Zemlyanichenko, Kadievich 2004 - Kalinin N. N., Zemlyanichenko M. A., Kadievich A. Architect of the Highest Court. Simferopol, 2004. In Russian. 
Kilesso 1983 - Kilesso S. K. Crimean Architecture. Kiev, 1983. In Russian. Kizilov 2011 - Kizilov M. B. Crimean Judea: Essays on the history of Jews, Khazars, Karaites and Krymchaks in Crimea from ancient times to the present day. Simferopol, 2011. In Russian.

Kotlyar 2015 - Kotlyar E. R. Morphology of design symbols in the Karaite decorative and applied art. Volume of scientific works of the international scientific conference of the Eurasian Scientific Association. Part 2. 2015. P. 325-327. In Russian.

Kovalenko 1999 - Kovalenko A. I. On some stylistic features of the Crimean architecture. Culture of the peoples of the Black Sea region: Academic Journal. 1999. 10. P. 51-54. In Russian.

Likhachev 2006 - Likhachev D. S. Omnibus edition: Thoughts about life, history, culture. Moscow, 2006. In Russian.

Lotman 1992 - Lotman Y. M. Symbol in the system of culture. Y. M. Lotman. Selected papers. T. 1. 1992. P. 191-199. In Russian.

Lotman 2000 - Lotman Y. M. Semiosphere. Saint Petersburg, 2000. In Russian.

Musaev 1964 - Musaev K. M. Grammar of the Karaite language. Phonetics and morphology. Moscow, 1964. In Russian.

Okhotnikova 2014 - Okhotnikova E. V. Art Nouveau in Russia and in Italy: cultural reception: theses of dissertation of the candidate of cultural studies. Moscow, 2014. In Russian.

Orbeli 1963 - Orbeli I. A. The Problem of Seljuk Art. Works of the International Congress on Iranian Art and Archeology. Erevan, 1963. P. 150-155. In Russian.

Prokhorov, Khrapunov 2013 - Prokhorov D. A., Khrapunov N. I. A Brief History of Crimea. Simferopol, 2013. In Russian.

Rempel, Vyaznikovtseva 1935 - Rempel L. I., Vyaznikovtseva T. V. The Age of Art Nouveau in Moscow. Architecture of the USSR. 1935. 10-11. P. 91. In Russian.

Sarabyanov 1989 - Sarabyanov D. V. Art Nouveau. Moscow, 1989. In Russian.

Sarach 1997 - Karaite People's Encyclopedia. Vol. 3. Language and folklore of the Karaites Ed. by M. S. Sarach. Moscow, 1997. In Russian. Tsalik 2012 - Tsalik S. Evpatoria. Walks around the Little Jerusalem. Simferopol, 2012. In Russian.

Zaskoka 2009 - Zaskoka V. M. The Karaites of Evpatoria: history, culture, architecture: short essay. Simferopol, 2009. In Russian. 